\title{
Consumer Protection in E-Commerce: A Case Study on Lodging Applications
}

\author{
Durianto Darmadi ${ }^{1 *}$, Riyadi Slamet ${ }^{1}$, Santiago Faisal ${ }^{1}$ \\ ${ }^{I}$ Department of Law, Universitas Borobudur, Indonesia, \\ "Corresponding author. Email: darmadiduriantoxx@gmail.com
}

\begin{abstract}
As the world no longer has boundaries with everyone being connected to the internet, we can access information from other parts of the world in an instant, without having to go anywhere. The internet makes it easy for us to access data and news. In addition, the internet provides convenience in doing business. For example, in the lodging business, lodging services can be booked via an online application. Undeniably, many online lodging applications, including OYO, have penetrated the Indonesian market, even though OYO's head office is not in Indonesia. This is the impact of globalization, and this growing trend has sparked our interest in conducting this research. Our research began when the National Consumer Protection Agency (BPKN) received a lot of complaints on OYO from consumers in September 2020. Like a two-sided coin, this incident shows a positive side that the public is already aware of their rights. Consumers are aware of the laws that can protect their rights, such as Law Number 8 of 1999 concerning Consumer Protection and Law Number 11 of 2008, which discusses Information and Electronic Transactions. However, consumers in Indonesia still prefer to settle e-commerce cases through a nonlitigation path. This research aims to uncover the legal protections for e-commerce consumers, especially in lodging services, and the process of dispute resolution within the National Consumer Protection Agency (BPKN) on complaints about e-commerce-based lodging services. This research aims to find out the root causes of ecommerce problems in lodging services, especially application-based ones (in the case of OYO), and to find out how the settlement process is conducted after a dispute occurs between consumers and e-commerce applicationbased lodging services providers. Apart from these two objectives, our research puts forward several suggestions with the hope that consumer rights can be quickly restored and business actors can carry out their obligations in full.
\end{abstract}

Keywords: E-commerce, Consumer Protection Agency, Consumer Protection Act.

\section{INTRODUCTION}

Indonesia is a country that adheres to an economic democracy that prioritizes the interests of the people. [1] For the welfare of the Indonesian people, efforts are needed to build long-term partnerships that mutually strengthen the economic sector of the people, the private sector, and StateOwned Enterprises to create a strong economic resilience. The development of various types of industry must be in accordance with the principles of economic democracy.

The implementation of the Indonesian economy is in line with the mandate of Article 33 paragraph (4) of the 1945 Indonesian Constitution that a national economy must be carried out based on economic democracy with the principles of togetherness, efficiency with justice, sustainability for the future, good environmental governance, independence, the maintainance of the balance in the progress and the unity of the national economy of Indonesia.

The development of modern life today has driven many changes in the lifestyle of numerous people, including those in Indonesia. Modern life requires everything to be faster and more practical, including fulfilling the needs of the people. This encourages many industries in Indonesia to take advantage of current technological developments. The use of technology nowadays helps many people to make ends meet. Apart from communicating, people use technology to do transactions online. Even though 
technology facilitates people's activities, online transactions put the community as consumers in a weak position because a consumer and a business actor do not meet directly in the process. This creates potential losses to consumers.

As the world no longer has boundaries with everyone being connected to the internet, we can access information from other parts of the world in an instant, without having to go anywhere. The internet makes it easy for us to access various types of data and news. Likewise, the internet also makes it easy for business actors to run their businesses. In the lodging business, for example, lodging can be booked through an online application without consumers having to book it on the spot. This definitely puts people traveling out of town at ease. Currently, many lodging businesses with easy transaction services based on online applications have emerged in Indonesia, such as OYO and RedDorz. In this research, we will focus on OYO.

OYO (On Your Own) is a unicorn company from India, a startup engaged in the hospitality sector founded in 2013. This lodging service officially started its business in Indonesia in 2018 with an investment of 100 million US dollars. Currently, OYO has collaborated with several major regions in Indonesia.

The entry of foreign business actors into Indonesia is one of the impacts of globalization. Every country is obliged to guarantee the safety and protection of its people. Therefore, to guarantee consumers' rights as recipients of a good or service, a government agency that specifically handles consumer protection issues, namely the National Consumer Protection Agency ((BPKN), was formed. This agency is a special agency that handles complaints about consumer rights that business actors fail to fulfill in accordance with Law Number 8 of 1999, which covers consumer protection.

This research began when the National Consumer Protection Agency (BPKN) received many consumer complaints regarding OYO in September 2020. Like a two-sided coin, this incident shows a positive side that the public is already aware of their rights as consumers. They are aware of the laws that can protect their rights, such as Law Number 8 of 1999 concerning Consumer Protection and Law Number 11 of 2008, which discusses Information and Electronic Transactions. However, consumers in Indonesia still prefer to settle ecommerce cases through a non-litigation path.
In this study, we identified two problem formulations. First, what are the legal protections for e-commerce consumers, especially in lodging services? Second, how is the dispute resolution process carried out by the National Consumer Protection Agency (BPKN) regarding complaints against e-commerce lodging services?

This study aims to uncover what legal protections consumers of e-commerce lodging services, especially application-based ones (OYO). It also seeks to obtain and find out the dispute resolution process carried out by the National Consumer Protection Agency (BPKN) regarding complaints against e-commerce lodging services.

\section{RESEARCH METHOD}

The research method used in this research is an empirical juridical method by analyzing primary data and some secondary data. The primary data investigated are regulations related to citizenship, while the secondary data are legal literature, related journals, and dictionaries related to the problems in this research. Thus, this research refers not only to a collection of material in the form of legal theories, concepts, principles, and related regulations but also to the reality in society as a legal phenomenon for the society as consumers. All the data needed by researchers in assessing this problem were collected using the literature review technique.

The data were then analyzed qualitatively by conducting an in-depth analysis. Researchers conducted in-depth interviews and focus group discussions on obtaining the required empirical data. The interviewees were selected purposively from various backgrounds such as the staff of the government, related institutions and practitioners and academics.

\section{RESULT AND DISCUSSION}

The development of people's lives in a country has an impact on the environment in that country. In accordance with the Preamble of the 1945 Constitution of the Republic of Indonesia, the Indonesian government has many objectives, one of which is to protect every element of the nation and all Indonesians. In addition, the 1945 Constitution as the basis for existing regulations needs to provide legal protection to guarantee the rights of every Indonesian.

Business actors now have to keep up with the demand in every aspect of the life of a community. 
The life of modern society today demands that everything be faster and more practical, including in fulfilling the daily needs of the people. This encourages many industries in Indonesia to take advantage of current technological developments. The use of technology today helps many people to meet their daily needs. Apart from communicating, technology is also used by the public to do transactions online. Specifically, technological developments enable people to buy and sell goods and/or services without any face-to-face interactions. Instead, these activities can be done through a virtual site where merchants only need to insert pictures and descriptions of their business.

As commonly known, law enforcement to create harmony within the society to adjust to the current development is not easy to carry out because, in reality, this is a complex human problem. [2] At the same time, the government of Indonesia needs to provide protection to every citizen. In the economic field, for example, in line with economic development in Indonesia, the government must provide protection to consumers in buying and selling transactions.

The National Consumer Protection Agency (BPKN) is one attempt by the state to provide legal protection for consumers. In carrying out its duties, the National Consumer Protection Agency (BPKN) gives advice and considerations to the government to provide protection for consumers, as stated in Law Number 8 of 1999 concerning Consumer Protection. The National Consumer Protection Agency (BPKN) is appointed by a presidential decree and is responsible directly to the president.

According to Article 3 of Law Number 8 of 1999 concerning Consumer Protection, consumer protection has several objectives: 1) increasing consumers' awareness, ability, and independence; 2) uplifting the dignity of consumers; 3 ) increasing the empowerment of consumers in choosing the goods and services they want, determining and claiming their rights; 4) creating a protection system for consumers with elements that meet the aspects of legal certainty and information disclosure; 5) raising awareness of business actors regarding the importance of protecting consumer rights; and, 6) improving the quality of goods and/or services that ensure the fulfillment of consumers' security and safety.

\subsection{Legal Protection of E-commerce Consumers, Especially in Lodging Services}

Efforts to develop consumer protection cannot be separated from international and national dynamics. All of these things affect the dimensions of legal, policy, institutional, logistical transactions, and management of protection for consumers.

In order to achieve the noble ideals of Indonesia, Article 33 paragraph (4) of the 1945 Republic of Indonesia Law has interpreted that "The national economy shall be implemented on the basis of economic democracy with the principles of togetherness, justice efficiency, sustainability, good environmental governance, independence, and balance between progress and national economic unity." It is necessary to provide justice for business actors and consumers in the practice of buying and selling.

The current development of the internet opens up opportunities for business actors to run their businesses. The actors offer their business through a variety of techniques and methods, one of which is through an e-commerce sales system.

Online selling is a multidisciplinary subject covering various fields of work involved. For example, engineering is involved in providing networks and telecommunications, securing, storing, and retrieving data from multimedia. [3] Through digitalization, Indonesia in the modern era has developed many sectors, such as the tourism sector. Business actors market their businesses, including hotels, tourist attractions, travel, and even lodging houses, online by utilizing technology.

Lodging business in the current era makes it easier for consumers to book lodging through an online application without having to order it on the spot. This definitely puts people traveling out of town at ease.

The great enthusiasm of the people in traveling provides a great chance for the tourism business to nourish. Graph 1 below portrays the results of a survey by dailysocial.id regarding budget hotel reservation method preference.

Graph 1. People's Travel Destination Survey [4]

Travel Destination Survey

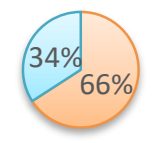

$\square$ Traveling on vacation $\square$ Travel for work 
The data above explain that respondents often traveled out of town for vacation rather than for work purposes.

Dailysocial.id also conducted a survey on how people book lodging, with the results as follows:

Graph 2. Community Travel Destination Survey.[5]

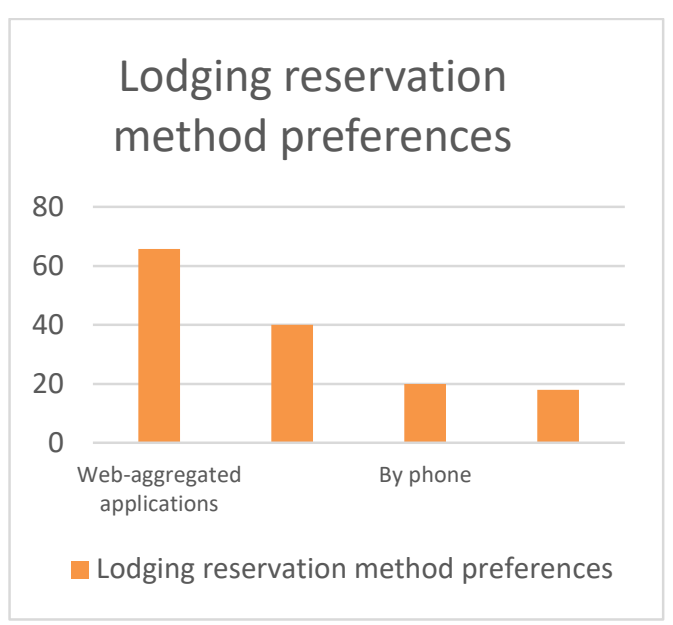

The data above shows that respondents prefer to make hotel reservations, especially budget hotels, using applications or websites rather than other methods.

Application-based lodging service is one of the trading forms that use an electronic system (ecommerce). The Government Regulation Number 80 of 2019 concerning PMSE regulates the following matters that must be considered in conducting a business using e-commerce media:
a. PMSE implementation
b. Business actors' obligations
c. Protection of personal data
d. Dispute resolution

Nowadays, many countries, including Indonesia, are experiencing an emergency situation due to the COVID-19 pandemic, causing a significant drop in the economy in various sectors. According to the data from Katadata/GDPVenture, the hotel or lodging network sector is one of the sectors whose transactions have declined due to the pandemic outbreak. In several large areas in Indonesia, hotels are closed due to COVID-19. For example, in West Java, around $41 \%$ of hotels are closed, while Bali and Yogyakarta are about $23 \%$ and $14 \%$ respectively. [6]
Despite the ease in accessing lodging through the application, it also faces many obstacles, such as failed transactions on the application, double bookings, unilaterally canceled bookings, unclear and/or rejected refund processes, unsatisfactory property facilitation, and misinformation between the application and the property operator. This study is triggered by a phenomenon that there are many consumer complaints regarding the e-commerce sector to the National Consumer Protection Agency (BPKN) from 2017 to 2020, which occupied the third rank with a total of 185 complaints. [7]

The purpose of establishing the National Consumer Protection Agency (BPKN) is stated in Article 3 of Law Number 8 of 1999, which in general, the National Consumer Protection Agency (BPKN) has a function to protect consumer rights and to enhance consumer dignity.

Various issues that need to be considered and often found in digital economy issues are as follows:

a. The startup ecosystem has not been mature;

b. E-commerce scams;

c. Transaction security;

d. Personal data security;

e. False information;

f. Acquisition of foreign e-commerce startup companies;

g. Legal territoriality;

h. Zone Improvement Plan (ZIP) is not in accordance with regional development;

i. Financial transactions are not well monitored;

j. Decreased intermediary;

k. Unclear tax subject and object; and

1. The absence of an e-commerce database.

In its trading process, the electronic lodging services shall guarantee the fulfillment of business actors' obligations for the interest of consumers. In this e-commerce business, several parties are involved, such as lodging service providers, PMSE providers (platform), consumers, and payment system providers. Such parties are obliged to organize complete data and information for consumers who will use online-based lodging (ecommerce). 
a. Lodging service providers

In the pre-transaction process, the service providers must provide actual, clear, and correct information concerning the offered services, including facility, tariff, and other things. They must be open to information and communication if additional information is needed. Then, in the transaction process, the providers should meet consumer rights in terms of security and comfort. Also, they should ensure that the available facilities are as promised. In the post-transaction process, the providers give consumers access to complaints and assessments regarding the damage or loss of goods.

\section{b. PMSE providers (platform)}

In the pre-transaction process, PMSE providers must give correct information and warnings to be noticed by consumers. They also should provide a safe and user-friendly electronic system and credible operators. In the transaction process, PMSE providers should pay attention to the reliability of the electronic system, and minimize potential errors such as double booking, fail connection in booking confirmation to operators, and unilateral cancellations. In the post-transaction process, it is necessary to provide complaint access, clear resolution mechanisms, and maintain the confidentiality of consumers' personal data.

c. Payment system providers

In the transaction process, payment system providers should have a reliable electronic system to avoid potential payment problems such as a successful payment that the platform provider does not recognize. Then, the payment system should provide complaints access and give a responsive resolution mechanism in the post-transaction process.

To provide legal protection for consumers from unfulfilled consumer rights, the government has made interrelated regulations to protect consumer rights. Consumers may complain about their unfulfilled rights to the National Consumer Protection Agency (BPKN) according to Article 34 paragraph (1) point $f$ of Consumer Protection Law concerning the duties of the National Consumer Protection Agency (BPKN).

A large number of internet users in Indonesia has resulted in the rapid growth of digital startup companies. This also triggers the entry of foreign businesses into Indonesia, for example, a lodging startup company such as OYO. OYO is a unicorn startup company from India, which officially started its business in Indonesia in 2018 with an investment of US\$ 100 million. OYO (On Your Own) is a company engaged in the hospitality business sector, and its head office in India was established in 2013. Currently, OYO has collaborated with some inns in big cities in Indonesia.

One of the National Consumer Protection Agency's (BPKN) duties is to conduct research on goods or services that strongly related to consumer safety [8]. BPKN's study on the safety of OYO's consumers showed that there are some obstacles in OYO's lodging services.

Further, in order to protect consumer rights, the Minister of Trade has issued a regulation as stipulated in Regulation of Minister of Trade Number 50 of 2020 concerning Business Licensing, Advertising, Development, and Supervision of Business actors in conducting Trade through Electronic Systems. The issuance of this regulation is deemed appropriate, considering the technology development is significantly increasing in Indonesia. Such regulation is also expected to have positive impacts on electronic commerce. [9]

\subsection{Dispute Resolution Process within National Consumer Protection Agency concerning Complaints against $E$ - Commerce Lodging Services}

Since the enactment of Law Number 8 of 1999 concerning Consumer Protection on April 20, 1999, the consumer protection issue has been seen as an important issue. The existence of such Law creates a strong bargaining position for consumers to enforce their rights as consumers. [10]

Like a two-sided coin, the high number of complaints submitted to the National Consumer Protection Agency (BPKN) also has positive and negative implications. Positively, it is implied that many people are aware of their rights as consumers. Also, the consumers are aware of laws that protect them as consumers, such as Law Number 8 of 1999 on Consumer Protection and Law Number 11 of 2008 on Information and Electronic Transactions.

Article 40 of the Law on Information and Electronic Transactions states that the government must facilitate and protect the public interests from all kinds of interference or misuse of Electronic Information and Electronic Transactions that disturb public order or harm others. Ministry of 
Communication and Information conducts the supervisory function on the implementation of this law.

Article 46 paragraph (1) of Law Number 8 of 1999 states that a dispute lawsuit can be filed by an individual as a consumer or a group of consumers, a Non-Governmental Organization for Consumer Protection (LPKSM) and government and/or a body who have suffered a quite significant material loss.

The process of e-commerce dispute resolution can be carried out through litigation in the scope of non-litigation and general courts. However, consumers, especially in Indonesia, tend to choose ecommerce dispute resolution through a nonlitigation path. This settlement process is taken based on an agreement between the business actor and the consumer.

The e-commerce dispute resolution through litigation path in the scope of general justice refers to the general court provisions, while the dispute resolution using non-litigation path (outside the court) is carried out by the Consumer Dispute Resolution Agency (BPSK). It aims to reach an agreement related to the form and amount of losses that should be indemnified by the business actors to their consumers. The process is also carried out by means of mediation, conciliation, or arbitration.

The consumer complaints can be submitted to the National Consumer Protection Agency through BPKN's official website at https://bpkn.go.id/, and consumers can select the consumer complaint section. When a consumer submits a complaint, the consumer must fill in personal data and the reported business actor. Consumers shall explain the problems in detail together with the evidence and mention their losses.

One of the complaints filed against OYO lodging services is concerning unpaid hotel booking refunds. The refund process from OYO should have completed within 7-14 days, but it can be extended up to 45 working days. Many consumers have not received the hotel booking refund, although it has exceeded such a time limit.[11]

This incident is widely discussed on social media. Besides the refund issue, there are various problems that were reported by consumers to National Consumer Protection Agency (BPKN). From the justice point of view, the consumer protection law must be able to fulfill consumer rights.
In resolving complaints submitted by consumers, Consumer Dispute Resolution Agency (BPSK) is required to issue a decision no later than 21 working days after the lawsuit is received. The objection to such a decision can be filed to local District Court no later than 14 (fourteen) days after the decision is notified. In the event the business actor does not file an objection within such grace period, the defendant (business actor) is deemed to have accepted such a decision. After a series of investigations is conducted and the Consumer Dispute Resolution Agency (BPSK) has given a decision, such decision needs to be requested for an executive decision by the District Court in the relevant jurisdiction.

The implementation of regulations in a country should not only focus on bringing justice but also paying attention to the deterrent aspect of those who violate it. The existing legal rules need to balance the life of society today, as quoted in the book written by Lili Rasjidi and friends regarding the Theory of Development Law, which explains that law is a tool to maintain order for people within their community. Note that the function of law is basically to maintain and preserve what has been achieved. [12] This is also in line with the Legal Development Theory put forward by Prof. Dr. Mochtar Kusumaatmaja, SH., L.LM., who stated that the Legal Development Theory globally contains many aspects. According to him, the Legal Development Theory is a legal theory known to many people in Indonesia because it was created by Indonesians by observing the dimensions and culture of Indonesian society. In broader terms, the Legal Development Theory uses a frame of reference on the way of life of the Indonesian people according to the principles of Pancasila. The Legal Development Theory also provides the basis for the function of law as a "means of community renewal" (law as a tool for social engineering) and law as an indispensable system for the Indonesian people as a country included in the category of developing countries. [13]

Moreover, as reported in the journalism forum of Antara, the National Consumer Protection Agency (BPKN) considered that the government needs to strengthen consumer protection in order to maintain domestic consumption, which will then help support the Indonesian economy. The chairman of BPKN, Ardiansyah Parman, said that in the context of epidemic management, the government or the state could realize and maintain people's purchasing power effectively amidst the economic situation facing an epidemic. [14] Legal reforms are needed in consumer protection in order to create a broader scope of consumer protection in the future and to 
prevent things that may cause harm to consumers from happening.

Consumer protection has been around for a long time in Indonesia, precisely since 1999 . However, the number of cases which are detrimental to consumers remains high. Consumers still find that it is difficult to sue for compensation, even just for trying, as consumers seem to be in a weak position in business transactions. This phenomenon arguably results from the Indonesian people's culturallyrooted habit with their principle of "take it or leave it." As such, consumers are positioned only as objects of business activities by business actors. The lack of public knowledge about agencies formed by the government regarding consumer protection requires the National Consumer Protection Agency (BPKN) to carry out activities that can raise community awareness regarding their rights as consumers in various economic sectors in Indonesia.

\section{CONCLUSION AND RECOMMENDATIONS}

\subsection{Conclusion}

Based on the results of the research and discussion as described by the authors, the following conclusions can be drawn:

The development of people's lives in a country has an impact on the environment in that country and requires many fields to support the needs of its people. Business actors now have to keep up with the demand in every aspect of a community's life. The life of modern society today demands that everything be faster and more practical.

a. With regard to legal protection for e-commerce consumers, especially in the field of lodging services, efforts to build protection for consumers cannot be separated from international and national dynamics because all of these things affect the dimensions of law, policy, institutions, logistical transactions, and the management of consumer protection. The development of the internet has opened up pathways for business actors to run their businesses and offer their products and/or services through various techniques and ways. One of them is through an e-commerce sales system. Indonesia in the modern era, through digitalization, has seen the rise of business sectors, including tourism, which utilize technology in their business activities, such as hotels, tourist attractions, travel agencies, and even lodging house businesses increasingly marketed online. Application-based lodging services are a form of trading through an electronic system (e-commerce), according to Government Regulation Number 80 of 2019 concerning PMSE, which regulates the implementation of e-commerce trading, including the implementation of PMSEs; Business actors' obligations; Personal data protection; and Dispute resolution. The purpose of establishing the National Consumer Protection Agency (BPKN) is stated in Article 3 of Law Number 8 of 1999. In general, BPKN has the function of protecting consumer rights and enhancing the dignity of consumers. Various issues that need to be watched out for and are often found in digital economy issues include the immature startup ecosystem, ecommerce scams, transaction security, personal data security, false information, acquisition of foreign e-commerce startups, legal territoriality, The Zone Improvement Plan (ZIP) which is not in accordance with regional developments, financial transactions which are not well monitored, decreased intermediary, unclear tax subject and object, and the absence of e-commerce database. In any e-commerce activity, a number of parties are involved, including lodging service providers, PMSE providers (platforms), consumers, and payment system providers. To carry out legal protection for consumers due to the unfulfilled rights of consumers by business actors, the state has made interrelated regulations so that consumer rights are protected. Consumers can also complain about their rights not being fulfilled to the National Consumer Protection Agency (BPKN) under Article 34 paragraph (1) point $\mathrm{f}$ of the Consumer Protection Law regarding the duties of the National Consumer Protection Agency (BPKN). In carrying out its functions, $\mathrm{BPKN}$ is also tasked with conducting research on goods or services related to consumer safety. Research on the safety of consumers who use lodging services at OYO, which has its head office in India, shows the obstacles found by the National Consumer Protection Agency (BPKN).

b. The dispute resolution process within the National Consumer Protection Agency on complaints about e-commerce lodging services, given the passing of Law Number 8 of 1999 dated April 20, 1999, concerning Consumer Protection, has made consumer 
protection an important issue. Like a coin that has two different sides, the number of complaints submitted to the National Consumer Protection Agency (BPKN) also has positive and negative sides. The consumer dispute lawsuit process, as stipulated in Article 46 paragraph (1) of Law Number 8 of 1999, can be carried out by a consumer or a group of consumers, a business actor, and the NonGovernmental Organization for Consumer Protection (LPKSM), and the government and/or agency that has suffered considerable material losses. The process for consumer complaints to the National Consumer Protection Agency can be done through the official BPKN website at the https://bpkn.go.id/ link by going to the consumer complaint section. In the case of consumer complaints filed to OYO lodging services, the complaints are related to the refunds for hotel booking that OYO has not paid. In resolving complaints submitted by consumers to the Consumer Dispute Resolution Agency (BPSK), the Consumer Dispute Resolution Agency is obliged to issue a decision no later than 21 working days after the lawsuit is received. This decision can be filed as an objection to the local District Court no later than 14 days after the decision is notified. After it has been decided by the Consumer Dispute Resolution Agency (BPSK), the decision needs to be requested for an executive decision to the District Court where the consumer is disadvantaged by a business actor. Legal reforms are required in consumer protection to create a broader scope of consumer protection in the future and avoid things that may cause harm to consumers. Consumer protection has been around for a long time in Indonesia, precisely since 1999. However, the number of cases that are detrimental to consumers remains high. Consumers still find it difficult to sue for compensation as consumers seem to be weak in business transactions. This phenomenon arguably results from Indonesian people's culturally-rooted habit with their principle of "take it or leave it." The lack of public knowledge about agencies formed by the government regarding consumer protection requires the National Consumer Protection Agency (BPKN) to carry out activities that can create community sensitivity regarding their rights as consumers in various economic sectors in Indonesia.

\subsection{Recommendations}

Based on the elaboration of the problems in this study, we made several recommendations to create legal reforms in accordance with the conditions of society so that consumers' rights can be quickly restored while business actors will carry out their obligations in full, as follows:

a. Cooperation between BPKN and the Consumer protection agency at the international level should be increased as more and more people are making sales through e-commerce not only on the national but also international level.

b. The National Consumer Protection Agency should be more active in providing counseling and information to business actors in order for them to carry out their obligations as business actors who are obedient to the rights of consumers protected under the Consumer Protection Law.

c. The Ministry of Communication and Information must be more active in collecting problems regarding e-commerce, especially lodging businesses. In practice, the Ministry of Communication and Information can open a direct service for complaints from the public regarding ecommerce issues.

d. OYO should open an official branch office in Indonesia that serves consumers' interests 24 hours a day.

\section{REFERENCES}

[1] Indonesia, "Ketetapan Majelis Permusyawaratan Rakyat Republik Indonesia Nomor XVI/MPR/1998," 1998.

[2] Faisal Santiago, MA Sebagai Benteng Terakhir (Peradilan) Penegakan Hukum, artikel dalam buku Akuntabilitas Mahkamah Agung Asosiasi Pimpinan Perguruan Tinggi Hukum Indonesia, Depok: PT. Rajagrafindo Persada, 2016.

[3] Sutan Remy Sjahdeny, E-commerce Dari Perspektif Hukum, Jurnal Hukum Bisnis, vol. 12, pp. 6, 2001.

[4] DailySocial.id. (2020, October 2). Budget Hotels Apps in Indonesia Survey 2017. DailySocial.id. https://store.dailysocial.id/post/laporan- 
dailysocial-budget-hotel-apps-diindonesia-2017

[5] Ibid.

[6] Data Katadata/GDPVenture. (2020, October 2). Hotel Tutup/Sementara Tutup Akibat COVID-19. databoks.katadata.co.id.

https://databoks.katadata.co.id/datapublish/ 2020/04/28/berapa-hotel-yang-tutupakibat-covid-19-di-5-wilayah-indonesia.

[7] Badan Perlindungan Konsumen Nasional. (2020, October 2). Pengaduan BPKN tahun 2017-2020. bpkn.go.id. https://bpkn.go.id/posts/show/id/1745.

[8] Indonesia, "Undang-Undang Nomor 8 Tahun 1999," 1999.

[9] ekonomi.bisnis.com. (2020, October 2). Permendag 50/2020 Hadir di Saat yang Tepat. ekonomi.bisnis.com. https://ekonomi.bisnis.com/read/20200527 112/1245209/permendag-502020-hadir-disaat-yang-tepat-

[10] Lathifah Hanim, Perlindungan Hukum Bagi Para Pihak Dalam E-commerce sebagai Akibat dari Globalisasi Ekonomi, Jurnal Pembaharuan Hukum, Vol. I No. 2, pp. 195, 2014.

[11] fixindonesia.pikiran-rakyat.com, (2020, October 2). Komplein Custumer Oyo Indonesia Soal Refund Dana Booking Hotel. fixindonesia.pikiran-rakyat.com. https://fixindonesia.pikiranrakyat.com/nasional/pr36667651/komplain-customer-oyo indonesia-soal-refund-dana-booking-hotel.

[12] Lili Rasjidi dan Ida Bagus Wiyasa Putra, Hukum Sebagai Suatu Sistem. Bandung : CV. Mandar Maju, 2003.

[13] Lilik Mulyadi, (2020, October 23). Teori Hukum Pembangunan Prof. DR. Mochtar Kusumaatmadja, $\quad S H ., \quad$ L. $\quad L M$. Badilum.mahkamahagung.go.id. https://badilum.mahkamahagung.go.id/upl oad_file/img/article/doc/kajian_deskriptif_ analitis teori hukum pembangunan.pdf

[14] antaranews.com, (2020, October 2). BPKN: Perlindungan Konsumen Perlu diperkuat. antaranews.com.

https://www.antaranews.com/berita/13307 46/bpkn-perlindungan-konsumen-perludiperkuat\#mobile-nav 